\title{
Conversion - The Act, the Process and Accompaniment
}

A preliminary remark: from the four available accounts only two were selected by the four language groups (two groups chose the story of Florence and two other groups chose the narration of Alexander). Now these are the two most structured narratives, those with whom we are undoubtedly more comfortable because they are clearly expressed. Further study would allow us to work on more diverse stories, and thus to honour the diversity of situations and conversions from different experiences. In this way, the methodology applied would benefit and be more accurate than just a few questions. But the exercise we have carried out, in my opinion allows us to develop six points.

\section{Tensions in our exercise in reading and listening to the narratives}

By reading and listening to the stories of conversion, we felt two tensions:

- the tension between what is said and what is not said. This is the principle of the story, given a moment of human history. The story does not clearly say what wants to be said and what seems important to be said. The story does not say everything.

- the tension between a life interpreted by the story and what has really been experienced in real life. This is already a re-reading of the reality, and therefore it is already an interpretation. For the reader or listener, it is tempting but dangerous to over-interpret. 
- the tension between discretion and intimacy - "The converted says: I changed". There is also an apologetic trend - The person responsible for the catechumenate told us that "These are proofs that God exists."

But the biggest tension is perhaps that between the narrated experience and our experience. We could have first narrated our own conversion stories ourselves. Anyway, catechists should themselves write their own conversion story first. This could be part of their formation. In order to acknowledge and to serve the action of the Holy Spirit in those being catechized, do we not first have to identify the Holy Spirit's action ourselves?

\section{The words of conversion, words of faith?}

We discussed again the word "conversion" and its meaning. In his account, Alexander, moreover, rejects it. The problem of vocabulary raised by Joël Molinario in his reaction on the issue thus remains unclear, despite our reading stories: Initial conversion and/or permanent conversion, conversion to the community and/or community conversion?, conversion of our ways of thinking and acting ... Work on conversion calls not only to specify the vocabulary, but also to clarify the concept of conversion in its various facets.

On the part of the converts there is also a vocabulary problem: they do not always have the words to explain their conversion experience. We have read and heard about how this experience touches their most profound identity, their relations, their perception of transcendence, and of God ... Thus, Florence hardly speaks of God, Alexander is very "rational" in his story, the husband of Natasha uses the word "devil" in a natural way to describe the obstacles ... With Natasha and her husband we saw two different forms of expression. And Natasha's tears explained the most intimate, when there are no more words to explain. These are the words of faith, when she is at the beginning.

We must in any case perform a 'catechetical' listening, with the aim that the Word of God echoes in the conversion story and the latter is understood as "the alphabet of God" (cf. Enzo Biemmi's introduction to the theme). 


\section{Conversion and Church experience}

The Church can be found throughout the narrations studies. Now the first ecclesial mediation is made up of real people. The process of beginning to convert can be found in a meeting or even a word ... The relation of the converts to the Church is nevertheless a complex issue.

So we have to be careful. In reading and listening to stories, we are always on the narrative side. What is narrated is a re-telling of events as seen by the converted person (see point 1). This does not mean that what is said does not correspond to reality, but a personal study of the narration may render more sporadic roles to the priest, to the accompanying person, to the ones who welcomed... which is what may have actually happened. Whether in a positive or in a negative perception. What interests us is precisely this perception, one that comes from the experience of the converted. It is thus interesting to note that even if people initially have negative experiences of the Church, as soon as they experience conversion and are initiated to the experience of the Church, these experiences are left behind and are replaced by a positive perception. Hence the importance to propose an "ecclesial bath" without delay to those admitted. The relationship with the community remains an obvious constant.

No doubt, the current context calls for Catholicism to become a "Catholicism of conversion" and that we should find ways to introduce a dynamism of conversion in communities. Conversion is now the preferred mode of access to the faith and 'permanent conversion' the preferred method of "remaining in faith." We have also heard and read in the articulate narratives of the importance of interpersonal relationships and belonging to small groups. But the fragility of conversions denotes the fragility of our ecclesial mediations (sacramental, Word of God, liturgy ...) and of our community life. These are to be implemented in the service of the action of the Holy Spirit, not in the service of a "normality" in the church.

\section{From the "treasure" to the mystery of faith}

We entered into the profound life of a few people who told us their story of conversion (in writing or orally). It is like a treasure which has been entrusted to us. We still need to move from the treasure to the mystery of faith. We can rejoice in the phenomenon of conversions, we can be grateful to the converted 
and to their testimony. But we can go further: do these narrations lead us to the mystery of the faith? In doing so, they alert us to the humility of our actions and our catechetical methods, and the need to anchor them in the experience of life / faith.

We could also say that if the converts have led us, from their "secret" to the mystery of faith, then they have been our true "mystagogues". In return they invited us to be attentive to Mystagogy, not only as a catechetical method, but as a practice placing the mystery of faith at the heart of catechesis. A Mystagogy which is at stake in the experience of a relationship between Christian life, catechesis and liturgy.

\section{The period of conversion as a vocation}

Does not the vocation to conversion unfold over time? We talk about initial conversion, permanent conversion, continuous conversion ... We talk about time, accompaniment, discernment ... which allows us to virtually articulate these concepts is an accompanying catechesis and to support conversion in the sense of accompaniment and supporting the vocation to conversion. Does not each conversion call the person to a particular vocation? Now the difficult transition from conversion to vocation is settled over time. This can be a daunting task for converts who are primarily prompted to the uniqueness of their conversion experience and who fear the "routine" of faith. But we also know that without this conversion there may be no tomorrow. The first vocation of the converted is thus consenting to the duration of the conversion, trusting the action of the Spirit and believing in a faith that grows without personal intervention.

This is the most difficult challenge today: initiation to the faith in time, a conversion that lasts, that unfolds in Christian life itself seen as a vocation. Using the liturgical year is one of the possible paths.

\section{Need to work on this issue in catechetical theology}

It is therefore necessary to continue to work on the issue of conversion in catechetical theology. We noted the interest in doing so by sharing our different contexts in Europe. 
For this task, we also noted the importance of entering into an interdisciplinary dialogue with the social sciences, where this is possible. Understanding the phenomenon of conversion as both individual and ecclesial, we cannot forego an anthropological reflection, especially today, given the anthropological crisis in our Western societies. It is also important to integrate the economic environment and our overall social context in our reflection. It seems, for example, that we can live very well without God today, yet there are conversions ... Catechetical theology therefore cannot do without a theology of the Holy Spirit. The first consequence to master is the necessity of a catechesis that must do everything to promote conversion knowing that it is primarily a matter of the meeting of the mystery of each person with the mystery of God.

Translated by Carl-Mario Sultana, University of Malta 